\title{
Chemical Effect of Chlorination Process on Antibiotic Resistant Bacteria
}

\author{
Salwa M. Samir ${ }^{*}$, Samar Samir Mohamed ${ }^{2}$, Shaban M. Ahmed ${ }^{1}$, Yousseria M. \\ Shetaia $^{2}$, Kamel M. Mohammed ${ }^{1}$ and Gamila E. El-Taweel ${ }^{1}$ \\ ${ }^{1}$ Water Pollution Research Department, National Research Center, Dokki, Giza, \\ Egypt. \\ ${ }^{2}$ Microbiology Department, Faculty of Science, Ain Shams University, Cairo, Egypt.
}

\begin{abstract}
CURRENT study was conducted to evaluate the effectiveness of chlorine as a simple and cheap application to inactivate antibiotic resistant bacteria. To achieve this aim, different doses of chlorine $(1.0,1.5,2.0,2.5$ and $3 \mathrm{mg} / \mathrm{l})$ were introduced to antibiotic resistant and sensitive isolates of Salmonella typhimurium as an example of Gram negative bacteria for 20 min contact time. The same chlorine doses were introduced to both antibiotic resistant and sensitive isolates of Staphylococcus aureus as an example of Gram positive bacteria for the same contact time. The antibiotic resistant isolates were obtained from antibiotic resistance genetic transformation experiment, which proves that antibiotic resistance in the aquatic environments was occurred by horizontal gene transfer(mainly genetic transformation). The obtained results showed that, antibiotic resistant and sensitive bacteria have the same chlorine susceptibility in either Gram negative and positive pathogenic bacteria. Whereas, the chlorine susceptibility in antibiotic sensitive and resistant isolates of Salmonella typhimurium (Gram negative bacteria) was relatively higher than chlorine susceptibility in antibiotic sensitive and resistant isolates Staphylococcus aureus (Gram positive bacteria). Where, $3 \mathrm{gm} / 1$ chlorine dose was able to make complete reduction of each of resistant and sensitive Salmonella typhimurium at $20 \mathrm{~min}$ contact time. Whereas, at the same chlorine dose $(3 \mathrm{mg} / 1)$ and contact time $(20 \mathrm{~min})$, Staphylococcus aureus still culturable $(7.0 \times 10$ and 9.0x10 CFU/ml) for sensitive and resistant isolates, respectively. And statistical analysis found that there was inverse proportion between chlorine dose and the bacterial counts in both pathogenic bacterial isolates (antibiotic sensitive and resistant).
\end{abstract}

Keywords: Chlorination, Antibiotic resistance, Pathogenic bacteria, Genetic transformation.

\section{Introduction}

Antibiotic resistant bacteria are considered one of the most dangerous emerging water borne contaminants as a result of extensive use of antibiotics in human diseases treatment and in veterinary practices as growth promoters. Further spread of antibiotic resistance among pathogens such as Salmonella typhimurium and Staphylococcus aureus is becoming one of the most relevant problems in the field of infectious diseases treatment [1-5]. Recent studies showed that morbidity and mortality rates were doubled in case of antibiotic resistant infections. Also, the length of treatment period increased requiring more effective antibiotics or/and antibiotic cocktails [6]. The spread of antibiotic resistance is mainly due to horizontal gene transfer along with selective pressure from the environment, among the bacteria which can transfer genetic material among a wide variety of bacterial species and genera [7].

Disinfection of reclaimed water is necessary to control microbial health risks that would originated from water borne pathogens such as protozoa, viruses and bacteria. Among many kinds of water and wastewater disinfection processes, chlorination has gained a good acceptance commercially in many countries, because of its low cost and simple application [8]. Despite the fact that emerging many technologies and disinfections in wastewater treatment, chlorine and chlorine-based compounds are still

*Corresponding author e-mail: salwa_ados2008@yahoo.com

DOI: 10.21608/EJCHEM.2018.4959.1441

C2017 National Information and Documentation Center (NIDOC) 
the most widely used disinfectant agent in water and wastewater treatment over the world $[9,10]$. Efficacy of chlorine to inactivate pathogens is impacted by several factors, including chlorine concentration, $\mathrm{pH}$, contact time, and the bacterial pathogen strain; as the response of Gram negative bacteria against chlorine differ from Gram positive bacteria[11]. Many studies have shown that both chlorine and UV disinfection are effective in reducing concentrations of resistant bacteria $[12,13]$. Another study [14] also suggested that UV treatment followed by chlorine disinfection may provide enhanced reduction of antibiotic resistant bacteria (ARB) in wastewater effluent, albeit at significantly higher doses and contact times than are commonly employed. While Guo et al. suggested that the concentration of certain types of ARB may actually be enriched after UV treatment [15].

Chlorine gas reacts with water to form $\mathrm{HOCl}$ and hydrochloric acid $(\mathrm{HCl})$. Then, the $\mathrm{HOCl}$ dissociates into the hypochlorite ion $\left(\mathrm{OCl}^{-}\right)$and the hydrogen ion $\left(\mathrm{H}^{+}\right)$, according to the following reactions:

$$
\begin{aligned}
& \mathrm{Cl}_{2}+\mathrm{H}_{2} \mathrm{O} \Leftrightarrow \mathrm{HOCl}+\mathrm{HCl} \\
& -\mathrm{HOCl} \Leftrightarrow \mathrm{H}^{+}+\mathrm{OCl}
\end{aligned}
$$

The $\mathrm{OCl}^{-}$and $\mathrm{HOCl}$ species are commonly called free chlorine, which are extremely reactive with numerous components of the bacterial cell[12].

Salmonella typhimurium is a Gram negative pathogenic bacterium that considered the causative agent of many enteric water borne diseases. It also may found everywhere in soil, water, sewage and in food processing equipment. Salmonella has become one of the main causative agents of many enteric waterborne infections in human. Resistance in Salmonella typhimurium is recorded in many aquatic environments[16]. Whereas, Staphylococcus aureus is a Gram positive pathogenic bacterium which causes many diverse enteric infections worldwide. The cell wall structure of Staphylococcus aureus as Gram positive cocci, is responsible for their high tolerance to dehydration, dryness and other hard environmental conditions. Which explain their widespread distribution in the environment [17]. Also a bacterial pathogen is associated with a wide range of human dangerous diseases such as septicemia and pneumonia and a main pathogenic agent in intensive care units[18].
Methicillin resistant Staphylococcus aureus (MRSA) has become a global public health problem worldwide.MRSA strains cause hardto-treat infections because they are resistant to most types of the antibiotics such as $\beta$-lactams, macrolides and aminoglycosides [19].

Thus, this investigation was carried out to determine the effect of chlorination process on both Gram positive pathogenic bacteria (Staphylococcus aureus) and Gram negative pathogenic bacteria (Salmonella typhimurium). Also to evaluate the response of antibiotic resistant and sensitive pathogenic bacterial isolates towards the different chlorine doses.

\section{Materials and Methods}

Isolation and identification of pathogenic bacteria In this study, two pathogenic bacteria isolates (Salmonella typhimurium and Staphylococcus aureus) were used to evaluate the disinfection effect of chlorine on both antibiotic sensitive and resistant strain in a bench-scale inactivation experiment. These bacterial isolates were isolated from the inlet of Zenein wastewater treatment plant (ZWWTP) and identified according to the American Public Health Association (APHA)[20]. In brief, $200 \mu 1$ of wastewater sample was streaked on the surface of bismuth sulfite agar medium. Typical Salmonella typhimurium colonies usually develop a black color with or without metallic sheen. All suspected colonies were streaked on the slant of phenylalanine agar, incubated at $37^{\circ} \mathrm{C}$ for $24 \mathrm{~h}$, and a few drops of $\mathrm{FeCl}_{3}$ solution were added. The negative results (yellow color) were tested with urea broth. The negative resulted isolate would culture in triple sugar iron agar (TSI) medium to examine $\mathrm{H}_{2} \mathrm{~S}$ formation. Simmons citrate agar and XLD agar were used to examine the ability of Salmonella typhimurium to utilizecitrate and D-xylose, respectively as a source of energy. Salmonella typhimurium is positive towards $\mathrm{H}_{2} \mathrm{~S}$ formation also it can utilize citrate and D-xylose. On the other hand, $200 \mu 1$ of wastewater sample was streaked on Baird-Parker agar (BPA) surface. Typical Staphylococcus aureus colonies which has black, convex, shiny colonies 1-1.5 $\mathrm{mm}$ in diameter picked up and streaked on mannitol salt agar (MSA) and positive result is golden-like sheen colonies. Then, rabbit citrated plasma and blood agar media were used to examine coagulation and heamolysis reaction of Staphylococcus aureus.Positive coagulase test and complete lysis of red cells in the media around 
and under the colonies ( $\beta$ - heamolysis) confirmed that the isolated colony is Staphylococcus aureus. Then verified by metabolic fingerprint Biolog GEN IIIin which the reading was carried out automatically by the computerized Micro Station $^{\mathrm{TM}}$ system.[21].

\section{Antibiotic susceptibility test}

Susceptibility patterns of Salmonella typhimurium (22 isolates) and Staphylococcus aureus (24 isolates) were tested against the most common clinically used antibiotics in Egypt. A bacterial lawn (0.5 McFarland) of the above mentioned isolates was streaked onto the surface of Müeller Hinton agar (Oxoid, UK) plates using sterilized cotton swab then, the following antibiotics (tetracycline (TE-30 $\mu \mathrm{g}$ ), penicillin (P-10 $\mu \mathrm{g})$, streptomycin (S-10 $\mu \mathrm{g})$, erythromycin (E-15 $\mu \mathrm{g})$, vancomycin (VA-30 $\mu \mathrm{g})$, ciprofloxacin (CIP-5 $\mu \mathrm{g}$ ), cefoxitin (FOX-30 $\mu \mathrm{g}$ ) and sulphamethoxazol-trimethoprime (SXT$23.75 \backslash 1.25 \mu \mathrm{g})$ discs were placed onto the surface of the inoculated plates. The plates were then incubated at $37^{\circ} \mathrm{C}$ for $24 \mathrm{~h}$. The susceptibility test was determined by Kirby-Bauer method according to the Clinical and Laboratory Standards Institute (CLSI) guidelines; where the non susceptible and intermediate susceptible isolates were considered resistant isolates and susceptible isolates were considered sensitive ones [22].

\section{Genetic transformation experiment}

Pure cultures of sensitive isolates of Salmonella typhimurium and Staphylococcus aureus were chosen to conduct the horizontal gene transfer (genetic transformation) experiment according to Schultz[23] in order to obtain resistant copy of the same sensitive bacterial isolates. In brief, $1 \mathrm{ml}$ of ZWWTP effluent sample was added to 10 $\mathrm{ml}$ of TSB (Oxoid, UK) and incubated for $24 \mathrm{~h}$ at $37{ }^{\circ} \mathrm{C}$. Following the incubation, $1 \mathrm{ml}$ of lysate solution was added to the effluent sample and placed in a water bath $\left(\geq 60{ }^{\circ} \mathrm{C}\right)$ for $\geq 1 \mathrm{~h}$ to lyse the bacterial cells, releasing free DNA into the test tube. Following the lysing procedure, and a short cooling period, $1 \mathrm{ml}$ of the bacterial isolate culture (known to be sensitive to most used antibiotics) was added to the lysed effluent/lysate solution and then incubated for $24 \mathrm{~h}$ at $37^{\circ} \mathrm{C}$, allowing genetic transformation to occur. After incubation, antibiotic susceptibility test was repeated again by spreading a bacterial (genetically transformed) lawn onto the surface of Müeller Hinton agar plates using sterilized cotton swab, and the antibiotic discs were placed on the surface of the plate. Then, plates were incubated for $24 \mathrm{~h}$ at $37{ }^{\circ} \mathrm{C}$. The transformation results (resistance to the most used antibiotics) were measured and recorded regarding to the sensitive isolates. Then the sensitive and resistant bacterial strains were subjected to bench-scale inactivation experiment using different doses of chlorine disinfectant.

\section{Chlorination experiment}

Each pathogenic bacteria isolates (resistant and sensitive)was grown individually at $37^{\circ} \mathrm{C}$ for $24 \mathrm{~h}$ in TSB and then centrifuged at $8000 \mathrm{xg}$ for 20 min., the pellets then were washed twice carefully with sterilized distilled water to get rid of any organic matter in the media that may consume part of chlorine and give false results. Then the pellets were suspended in $10 \mathrm{ml}$ sterile distilled water (bacterial isolate suspension). The initial count of the tested bacterial strain was determined by poured plate method using ten-fold serial dilutions using plate count agar (Oxoid, UK). The count of each bacterial strain was repeated twice after each chlorine dose to detect the chlorination effect upon the bacterial growth reduction rate.

\section{Determination of residual chlorine}

Each $250 \mathrm{ml}$ Erlenmeyer flask (Eight flasks) containing $100 \mathrm{ml}$ distilled water were inoculated with $0.5 \mathrm{ml}$ of bacterial isolate suspension and then were injected with different chlorine doses $(0.5,1.0,1.5,2.0,2.5$ and $3.0 \mathrm{mg} / \mathrm{l})$ and was left for $20 \mathrm{~min}$. The experimental dosages were chosen based on previous studies and levels commonly employed in water treatment process[13-15]. An uninoculated chlorine water flask was used as negative control for this experiment. The determination of residual chlorine after each chlorine dose and 20 min contact time was carried out by N, N-diethyl-p-phenylenediamine(DPD) titration method according to APHA [20].

\section{Statistical analysis}

The relationship between the residual chlorine and the pathogenic bacterial counts at different chlorine doses at $20 \mathrm{~min}$, contact time was carried out using regression coefficient analysis $\left(\mathrm{R}^{2}\right)$ that processed by SPSS version 16.0, computer application.

\section{Results and Discussion}

Antibiotic resistance among pathogenic bacteria becomes health risk problem in the last years worldwide. The mortality and morbidity rates were doubled in case where antibiotic resistant infections were found[5]. Thus, this 
study was conducted to evaluate the disinfection effect by chlorine on both antibiotic resistant and sensitive pathogenic bacteria (Gram negative and Gram positive).

\section{Pathogenic bacterial resistance profile}

The results in Table 1 represent the resistance profile of Salmonella typhimurium and Staphylococcus aureus isolated from the inlet of ZWWTP towards the most clinically used antibiotics in Egypt. In case of Salmonella typhimurium, twenty two isolates were subjected to antibiotic susceptibility test and the results showed that, $100 \%$ of Salmonella typhimurium isolates were resistant to penicillin, erythromycin and vancomycin antibiotics. Whereas 17, 2, 20, 7 and 18 isolates out of 22 isolates were sensitive to each of tetracycline, streptomycin, ciprofloxacin, cefoxitin and sulphamethoxazoltrimethoprime antibiotics, respectively. On the other hand, 5, 20, 2, 15 and 4 isolates out of 22 isolates were resistant to each of tetracycline, streptomycin, ciprofloxacin, cefoxitin and sulphamethoxazol-trimethoprime antibiotics, respectively. While in case of Staphylococcus aureus, twenty four isolates were subjected to antibiotic susceptibility test and the results showed that, $100 \%$ of Staphylococcus aureus isolates were resistant to each of penicillin and erythromycin antibiotics. Whereas, $100 \%$ of Staphylococcus aureus isolates were sensitive to sulphamethoxazol-trimethoprime antibiotic.
At the same time, 23, 16, 6, 22 and 14 isolates out of 24 isolates were sensitive to tetracycline, streptomycin, vancomycin, ciprofloxacin and cefoxitin antibiotics, respectively. Finally, $1,8,18,2$ and 10 out of 24 isolates were resistant to each of tetracycline, streptomycin, vancomycin, ciprofloxacin and cefoxitin antibiotics, respectively. These results are similar to that obtained from studies conducted by Duran et al. and Ejovwokoghene et al.[24,25]. Ejovwokoghene et al.[24] studied the prevalence of antimicrobial resistance of Salmonella spp. in treated effluent and receiving aquatic milieu of wastewater treatment plants in Durban, South Africa. Their results concluded that $100 \%$ of 200 Salmonella spp. isolates were resistant to cefoxitin antibiotic while $100 \%$ were sensitive to tetracycline and sulphamethoxazoltrimethoprime antibiotics. Whereas 176 out of 200 and 1 out of 200 Salmonella spp. were resistant to streptomycin and ciprofloxacin, respectively. On the other hand, Duran et al.[25] studied antibiotic resistance susceptibility patterns in Staphylococcus aureus in clinical and environmental samples in Turkey. Their results stated that from 139 Staphylococcus aureus isolates; 57, 129, 84, 0, 57, 23 and 31 isolates were resistant to each of tetracycline, penicillin, erythromycin, vancomycin, ciprofloxacin, cefoxitin and sulphamethoxazol-trimethoprime, respectively.

TABLE 1. Antibiotic susceptibility profile of Salmonella typhimurium (22 isolates) and Staphylococcus aureus (24 isolates) isolated from the inlet of ZWWTP towards the most clinically used antibiotics in Egypt.

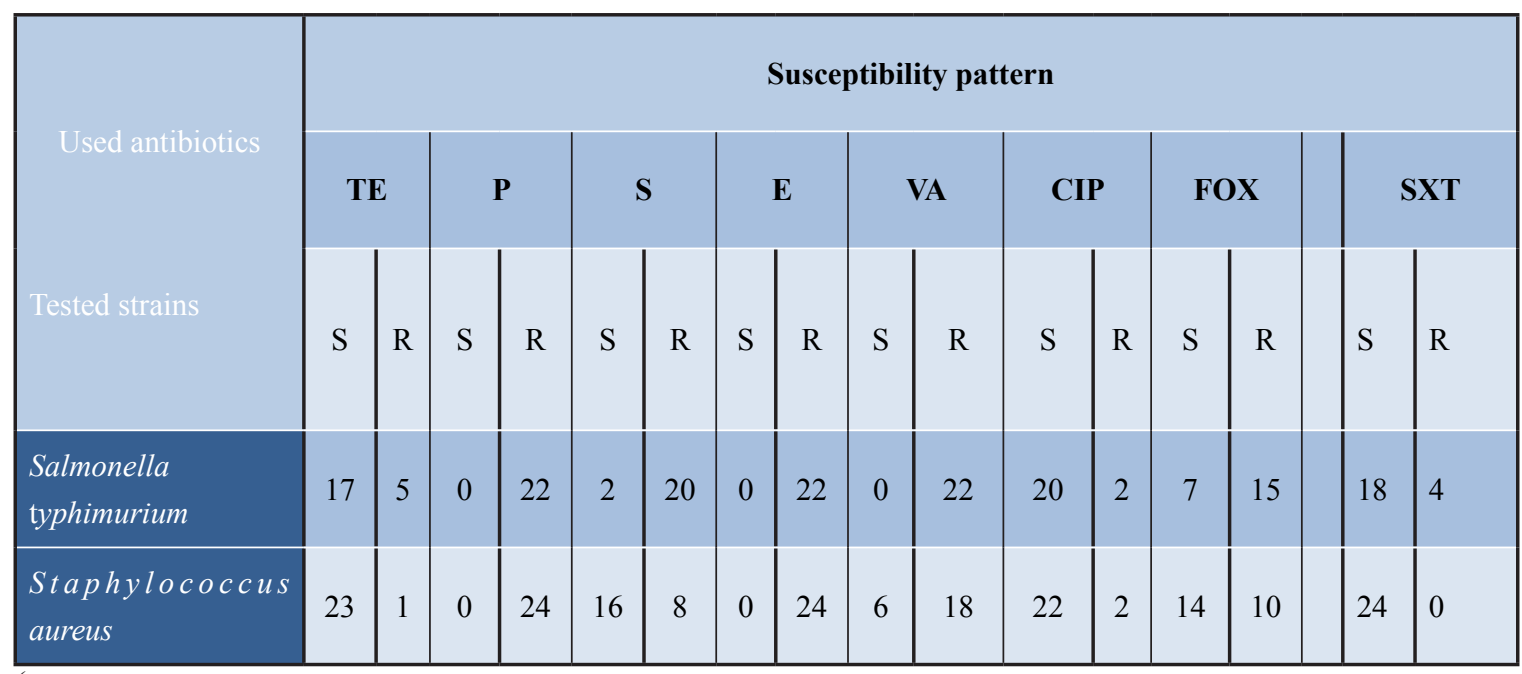

(TE) tetracycline, (P) penicillin, (S) streptomycin, (E) erythromycin, (VA) vancomycin, (CIP) ciprofloxacine, (FOX) cefoxitin, (SXT) sulphamethoxazol-trimethoprime.S: sensitive, R: resistant. 


\section{Genetic transformation}

The sensitive isolates of each of Salmonella typhimurium and Staphylococcus aureus that obtained from the inlet of ZWWTP were chosen to conduct the genetic transformation experiment. The results of Fig. 1 (Aand B), represented the antibiotic susceptibility pattern of Salmonella typhimurium strain before genetic transformation (the bacterial strain was sensitive to the most used antibiotics) and after genetic transformation (the bacterial strain was resistant to the most used antibiotics). On the other hand, the results of Fig. 2 (A and B), represented the antibiotic susceptibility pattern of Staphylococcus aureus strain before genetic transformation (the bacterial strain was sensitive to the most used antibiotics) and after genetic transformation (the bacterial strain was resistant to the most used antibiotics) which ensure that the resistant genes were transferred by horizontal genetic transformation process.

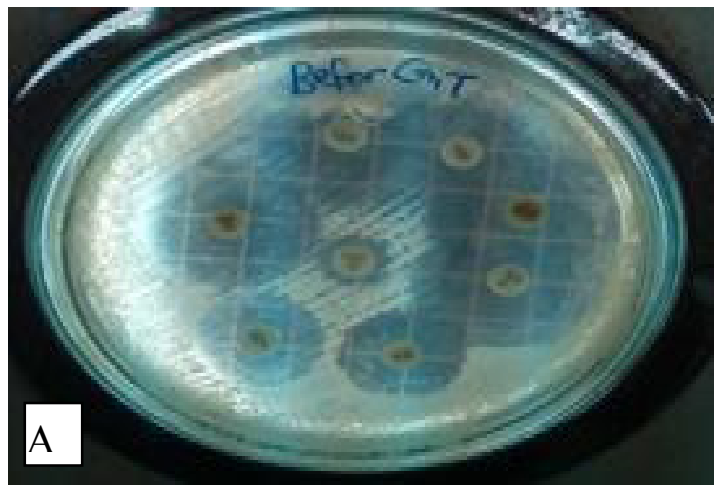

The obtained results demonstrated that the free DNA from treated wastewater, which contained an antibiotic resistant gene, was the main source for antibiotic resistance in the natural aquatic environment where wastewater is discharged. Other studies have also shown that wastewater treatment plants are the main source of resistance genes in the natural environment [26]. The bacteria in wastewater influent, and in treatment plants, as well as those present in the natural environment, are all exposed to other bacteria, giving the bacteria the chance to exchange genetic material or incorporate free DNA into their own genetic material via genetic transformation process. The same results of transformation phenomenon were obtained by Everage et al.[27]. Both sensitive and resistant strains were subjected to disinfection experiment using different chlorine doses.

Fig. 1. Antibiotic susceptibility pattern of sensitive Salmonella typhimurium isolate; (A): before genetic transformation (B): after genetic transformation.

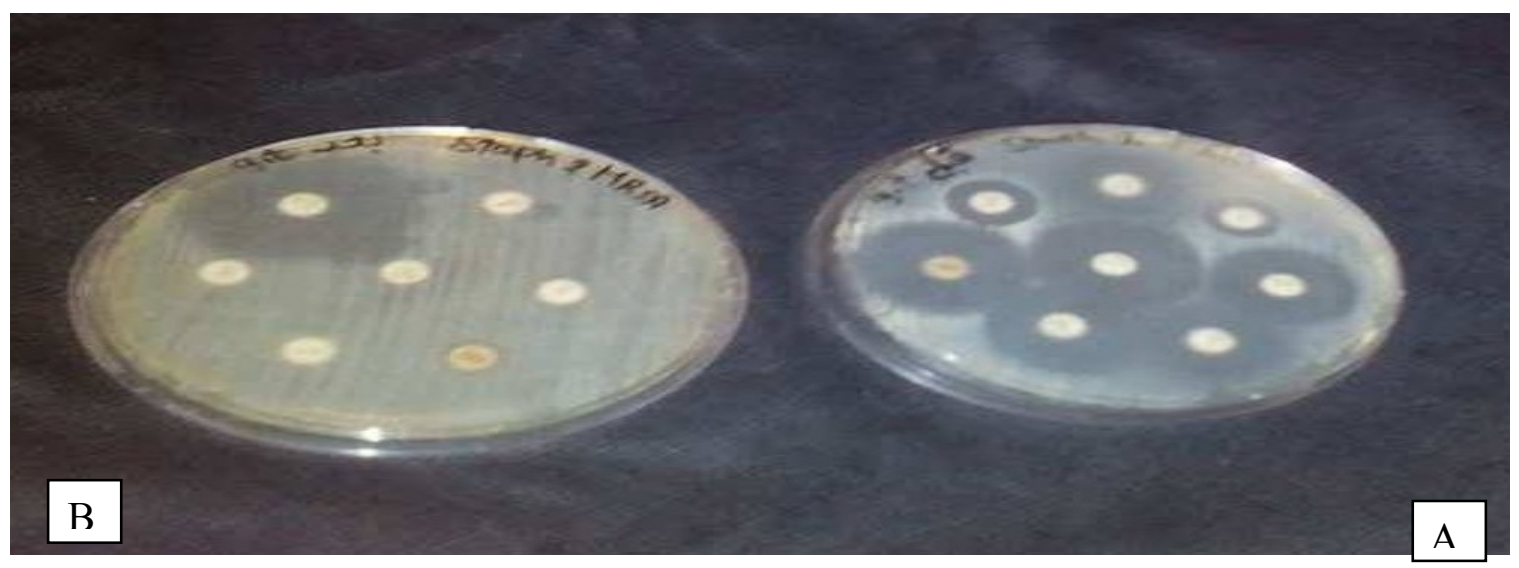

Fig. 2. Antibiotic susceptibility pattern of sensitive Staphylococcus aureus strain; (A): before genetic transformation (B): after genetic transformation. 
Effect of different chlorine doses on sensitive and resistant strains

The susceptibility of each sensitive and resistant Salmonella typhimurium to the chlorination process at the same chlorine doses $(0,0.5,1.0,1.5,2.0,2.5$ and $3 \mathrm{mg} / 1)$ for same contact time $(20 \mathrm{~min})$ was presented in Table 2. It was noted that, the initial counts of both sensitive and resistant Salmonella typhimurium were $7.9 \times 10^{6}$ and $9.4 \times 10^{6} \mathrm{CFU} / \mathrm{ml}$, respectively in case of negative control sample (without chlorine).At chlorine dose of $2.0 \mathrm{mg} / \mathrm{l}$, the bacterial count was reduced with more than 4 log count with removal percentage of $99.996 \%$ for sensitive Salmonella typhimurium and 99.991\% for resistant Salmonella typhimurium. Using $3.0 \mathrm{mg} / 1$ chlorine dose, both resistant and sensitive Salmonella typhimurium were completely removed. Also it is remarkable that, the residual chlorine concentration of each sensitive and resistant Salmonella typhimurium is relatively high which mean that the chlorine demand (consumed to get rid of bacteria) for its inactivation is relatively low dose. Which mean that Salmonella typhimurium is more susceptible to chlorination process. The statistical analysis of these results showed that, the regression $\left(\mathrm{R}_{2}\right)$ between the residual chlorine and sensitive Salmonella typhimurium count was 0.39 andthe regression $\left(\mathrm{R}_{2}\right)$ between the residual chlorine and resistant Salmonella typhimurium count was 0.31 . The statistical analysis also showed adecrease in Salmonella typhimurium counts with increase in chlorine dose (inversely proportional).

TABLE 2. Susceptibility of sensitive and resistant Salmonella typhimurium strains to different chlorine doses at 20 min contact time.

\begin{tabular}{|c|c|c|c|c|c|c|c|}
\hline \multirow{2}{*}{\multicolumn{2}{|c|}{$\begin{array}{l}\text { Removal } \\
\text { percentage }\end{array}$}} & \multirow{2}{*}{\multicolumn{2}{|c|}{$\begin{array}{l}\begin{array}{l}\text { Salmonella typhimurium count } \\
\text { (CFU/ml) }\end{array} \\
\text { Residual } \\
\text { chlorine }\end{array}$}} & \multicolumn{4}{|c|}{ Chlorine (mg/l) } \\
\hline & & & & \multicolumn{2}{|c|}{ Chlorine dose } & \multirow[b]{2}{*}{$\mathrm{R}$} & \multirow[b]{2}{*}{$\mathrm{S}$} \\
\hline $\mathrm{R}$ & $\mathrm{S}$ & $\mathrm{R}$ & $\mathrm{S}$ & $\mathrm{R}$ & $\mathrm{S}$ & & \\
\hline $0.000 \%$ & $0.000 \%$ & $9.4 \times 10^{6}$ & $7.9 \times 10^{6}$ & 0.00 & 0.00 & 0.00 & 0.00 \\
\hline $97.340 \%$ & $97.468 \%$ & $2.5 \times 10^{5}$ & $2.0 \times 10^{5}$ & 0.10 & 0.12 & 0.50 & 0.50 \\
\hline $98.968 \%$ & $98.949 \%$ & $9.7 \times 10^{4}$ & $8.3 \times 10^{4}$ & 0.25 & 0.30 & 1.00 & 1.00 \\
\hline $99.920 \%$ & $99.986 \%$ & $7.5 \times 10^{3}$ & $1.1 \times 10^{3}$ & 0.23 & 0.27 & 1.50 & 1.50 \\
\hline $99.991 \%$ & $99.996 \%$ & $8.1 \times 10^{2}$ & $1.0 \times 10^{2}$ & 0.40 & 0.42 & 2.00 & 2.00 \\
\hline $99.998 \%$ & $99.999 \%$ & $1.0 \times 10^{2}$ & $6.4 \times 10$ & 0.66 & 0.61 & 2.50 & 2.50 \\
\hline $100 \%$ & $100 \%$ & 0 & 0 & 0.71 & 0.68 & 3.00 & 3.00 \\
\hline
\end{tabular}

(S) Sensitive strain.

(R) Resistant strain.

On the other hand, the susceptibility of both sensitive and resistant Staphylococcus aureus to the chlorination process at the same of chlorine doses and contact time was represented in Table 3. It can be founded that, the initial counts of sensitive and resistant Staphylococcus aureus were 7.0 $\times 10^{6}$ and 9.6 $\times 10^{6} \mathrm{CFU} / \mathrm{ml}$, respectively in control sample (without chlorine). Whereas, at a chlorine dose of $2.0 \mathrm{mg} / \mathrm{l}$, the bacterial count was reduced with more than 3 log count reduction and removal percentage of $99.987 \%$ for sensitive Staphylococcus aureus and $99.989 \%$ for resistant Staphylococcus aureus, respectively. Using $3.0 \mathrm{mg} / \mathrm{l}$ chlorine dose (the dose at which Salmonella typhimurium was completely removed), both sensitive and resistant Staphylococcus aureus were still culturable by $7.0 \times 10$ and 9.0x10 CFU/ml, respectively.On the other hand, the results listed in Table 3 also showed that, the residual chlorine concentration of each sensitive and resistant Staphylococcus aureus is relatively low which mean that the chlorine demand for its inactivation is relatively high dose. The phenomenon which proves that, Staphylococcus aureus is more resistant to chlorination process. The statistical analysis of the obtained results showed that, the regression

Egypt.J.Chem. 62, No. 2 (2019) 
$\left(\mathrm{R}_{2}\right)$ between the residual chlorine and sensitive Staphylococcus aureus count was 0.29 and the regression $\left(\mathrm{R}_{2}\right)$ between the residual chlorine and resistant Staphylococcus aureus count was 0.32. The statistical analysis also showed a decrease in Staphylococcus aureus counts with increase in chlorine dose (inversely proportional).

Based on these results it can be concluded that, there is no difference in the removal rate of each of sensitive and resistant strains of both Salmonella typhimurium and Staphylococcus aureus as well. Also, both of sensitive and resistant strains require the same doses of chlorine for their inactivation. These results are similar to results obtained by Huang et al.,[28].

Huang et al, [28] and Sullivan et al, [29]showed that, exposing wastewater to chlorine did not select for tetracycline resistant bacteria, and the tetracycline resistant bacteria behaved similarly to that of sensitive bacteria. Also, the same study stated that there is still limited evidence showing that there is any difference between inactivation of antibiotic resistant bacteria and antibiotic sensitive bacteria in sewage to indicate selection of antibiotic resistant bacteria by chlorination. In addition, chlorine's efficacy to inactivate antibiotic sensitive and resistant bacterial pathogens is positively correlated with chlorine concentration and exposure time in the chlorine. Also these results are similar to results of Kouame and Haas[30].

From the above results it can be noted that, Gram negative bacteria (Salmonella typhimurium) were generally more sensitive to chlorine than Gram positive bacteria (Staphylococcus aureus). This phenomenon may back to difference in bacterial membrane and cell wall structural responses to chlorine exposure which make Gram negative bacteria more susceptible to chlorine [31]. The second evidence for Gram negative susceptibility to chlorine is that, $3.0 \mathrm{mg} / \mathrm{l}$ chlorine dose was able to completely remove sensitive and resistant Salmonella typhimurium whereas, the same chlorine dose was not able to remove sensitive and resistant Staphylococcus aureus at the same contact time.

TABLE 3. Susceptibility of sensitive and resistant Staphylococcus aureus strains to different chlorine doses at 20 min contact time.

\begin{tabular}{|c|c|c|c|c|c|c|c|}
\hline \multirow{2}{*}{$\begin{array}{l}\text { Removal } \\
\text { percentage }\end{array}$} & \multicolumn{2}{c}{$\begin{array}{c}\text { Staphylococcus aureus count } \\
\text { (CFU/ml) }\end{array}$} & \multicolumn{4}{c|}{ Chlorine ( mg/l) } \\
\cline { 5 - 9 } & \multicolumn{2}{c|}{ Residual chlorine } & \multicolumn{3}{c|}{ Chlorine dose } & & \\
\hline $\mathrm{R}$ & $\mathrm{S}$ & $\mathrm{R}$ & $\mathrm{S}$ & $\mathrm{R}$ & $\mathrm{S}$ & $\mathrm{R}$ & $\mathrm{S}$ \\
\hline $0.000 \%$ & $0.000 \%$ & $9.6 \times 10^{6}$ & $7.0 \times 10^{6}$ & 0.00 & 0.00 & 0.00 & 0.00 \\
\hline $95.520 \%$ & $95.571 \%$ & $4.3 \times 10^{5}$ & $3.1 \times 10^{5}$ & 0.08 & 0.06 & 0.50 & 0.50 \\
\hline $97.291 \%$ & $97.142 \%$ & $2.6 \times 10^{5}$ & $2.0 \times 10^{5}$ & 0.18 & 0.15 & 1.00 & 1.00 \\
\hline $98.989 \%$ & $98.785 \%$ & $9.7 \times 10^{4}$ & $8.5 \times 10^{4}$ & 0.21 & 0.20 & 1.50 & 1.50 \\
\hline $99.989 \%$ & $99.987 \%$ & $1.0 \times 10^{3}$ & $9.0 \times 10^{2}$ & 0.18 & 0.18 & 2.00 & 2.00 \\
\hline $99.990 \%$ & $99.998 \%$ & $9.0 \times 10^{2}$ & $1.1 \times 10^{2}$ & 0.44 & 0.40 & 2.50 & 2.50 \\
\hline $99.999 \%$ & $99.999 \%$ & $9.0 \times 10$ & $7.0 \times 10$ & 0.54 & 0.52 & 3.00 & 3.00 \\
\hline
\end{tabular}

(S) Sensitive strain

(R) Resistant strain

\section{Conclusion}

To evaluate the effect of chlorine on antibiotic resistant pathogenic bacteria, many experiments have been conducted. Based on the obtained results it can be concluded that, there is no difference in removal rate of sensitive and resistant isolates of Salmonella typhimurium and Staphylococcus aureus as well. Both of sensitive and resistant strains require the same doses of chlorine for their inactivation. In addition, chlorine's efficacy to inactivate antibiotic sensitive and resistant bacterial pathogens is positively correlated with chlorine concentration and exposure time. Finally, Gram negative bacteria were generally more sensitive to chlorine than Gram positive bacteria. 


\section{Acknowledgment}

The authors would like to thank and appreciate Dr. Gamila H. Ali, Professor of Hydrobiology for her technical support in this study.

\section{References}

1. World Health Organization (WHO), Emerging Issues in Water and Infectious Disease. 1-22, (2003).

2. Kumarasamy, K.K., Toleman, M.A., Walsh, T.R., Bagaria, J., Butt, F., Balakrishnan, R., Chaudhary, U., Doumith, M., Giske, C.G., Irfan, S., Krishnan, P., Kumar, A.V., Maharjan, S., Mushtaq, S., Noorie, T., Paterson, D.L., Pearson, A., Perry, C., Pike, R., Rao, B., Ray, U., Sarma, J.B., Sharma, M., Sheridan, E., Thirunarayan, M. A., Turton, J., Upadhyay, S., Warner, M., Welfare, W., Livermore, D.M., Woodford, N., Emergence of a new antibiotic resistance mechanism in India, Pakistan, and the UK: a molecular, biological, and epidemiological study. Lancet Infectious Diseases, 10, 597- 602, (2010).

3. Gao, L., Shi, Y., Li, W., Niu, H., Liu, J., Cai, Y., Occurrence of antibiotics in eight sewage treatment plants in Beijing, China. Chemosphere, 86, 665-671, (2012).

4. Torpdahl, M., Tsai-Ling L., Shiu-Yun L., Ishien L., Sung-Hsi W., Chien-Shun C., Human Isolates of Salmonella enterica Serovar Typhimurium from Taiwan Displayed Significantly Higher Levels of Antimicrobial Resistance than Those from Denmark. Int. J. Food Microbiol., 61, 69-75, (2013).

5. Abdel-Shafy, H. I., Mansour, M. S. M., Abdel-Shafy, S. H., Chemical and Biological Contamination of Drinking Water as Affected by Residual Chlorine Deterioration and Storing Period: Case Study in Sinai, Egypt. Egypt. J. Chem.60 (6), 1067- 1076 (2017).

6. World Health Organization (WHO), The world is running out of antibiotics, WHO report confirms. Available online.http://www.who.int/ mediacentre/news/releases/2017/running-outantibiotics/en/(2017).

7. Zhang, X.X., Zhang, T., Fang, H., Antibiotic resistance genes in water environment. Appl. Microbiol. Biotechnol., 82, 397-414 (2009).

8. Campos, C., New perspectives on microbiological water control for wastewater reuse. Desalination,

Egypt.J.Chem. 62, No. 2 (2019)
218, 34- 42 (2008).

9. Rusin, P., Gerba, C., Association of chlorination and UV irradiation to increasing antibiotic resistance in bacteria. Reviews of Environ. Contam. and Toxic, 171, 1- 52 (2001).

10. Davies, J., Sanitation: sewage recycles antibiotic resistance. Nature, 487, 302-317, (2012).

11. Virto, R., Sanz, D., Alvarez, I., Condon, S., Raso, J., Modeling the effect of initial concentration of Escherichia coli suspensions on their inactivation by chlorine. J. Food Saf. 25 (2), 120-129 (2005).

12. Childress, H., Sullivan, B., Kaur, J., Karthikeyan, R., Effects of ultraviolet light disinfection on tetracycline-resistant bacteria in wastewater effluents, J. Water Health 12, 404-409 (2014).

13. Yuan, Q., Guo, M., Yang, J., Fate of antibiotic resistant bacteria and genes during wastewater chlorination: implication for antibiotic resistance. Control, 10, 430-472 (2015).

14. Zhang, Y., Zhuang, Y., Geng, J., Ren, H., Zhang, Y., Ding, L., Xu, K., Inactivation of antibiotic resistance genes in municipal wastewater effluent by chlorination and sequential UV/chlorination disinfection, Sci. Total Environ., 125, 512-513, (2015).

15. Guo, M., Yuan, Q., Yang, J., Microbial selectivity of UV treatment on antibiotic-resistant heterotrophic bacteria in secondary effluents of a municipal wastewater treatment plant, Water Res. 47, 6388-6394 (2013).

16. Johnson, L., Shawn R. H., Laetitia C. M., Amy L. T., Heidi M., Michael G. S., Shawn L., Extracellular DNA-induced Antimicrobial Peptide Resistance in Salmonella enterica Serovar Typhimurium. BMC Microbiology, 13,115-118 (2013).

17. Kloos, W.E., Schleifer, K.H., Götz, F., The genus Staphylococcus. Chapter 63, vol. 2 1n: Balows, A., Trüper, H.G., Dworkin, M., Schleifer, K.H., editors. The Prokaryotes. 2nd ed. New York, Springer, 1369-1420 (1992).

18. Bassetti, M., Nicco, E., Mikulskam M., Why is community associated MRSA spreading across the world and how will it change clinical practice? Int. J. Antimicrob Agents, 34, 15-19 (2009).

19. Jarvis, W.R., Schlosser, J., Chinn, R.Y., Tweeten, S., Jackson, M., National prevalence of methicillinresistant Staphylococcus aureus in inpatients at US health care facilities. Am. J. Infect. Control, 


\section{5, 631- 637,(2007).}

20. American Public Health Association (APHA), Standard Methods for the Examination of Water and Wastewater $22^{\text {nd }}$ ed., Washington, D.C., (2012).20. Wiethan, J., Unger, J., Brunswik-Titze, A., Kümmerer, K., Occurrence and reduction of antibiotic resistant (pathogenic) bacteria in municipal sewage treatment plants. Intern. Water Assoc., World Congress, Berlin, 10, 15.-19 (2001).

21. Wiethan, J., Unger, J., Brunswik-Titze, A., Kümmerer, K., Occurrence and reduction of antibiotic resistant (pathogenic) bacteria in municipal sewage treatment plants. Intern. Water Assoc., World Congress, Berlin,10, 15.-19 (2001).

22. Clinical and Laboratory Standards Institute (CLSI), Performance standards for antimicrobial susceptibility testing. CLSI approved standard M100-S23. Clinical and Laboratory Standards Institute, Wayne, PA. (2013).

23. Schultz, D., Biology 155 General Biology I Laboratory Supplement. Nicholls State University, Thibodox, LA. (2006).

24. Ejovwokoghene, C., Odjadjare, A., Olaniran, O., Prevalence of antimicrobial resistant and virulent Salmonella spp. in treated effluent and receiving aquatic milieu of wastewater treatment plants in Durban, South Africa.Int. J. Environ. Res. Public Health, 12, 9692-9713 (2015).

25. Duran, N., Ozer, B., Gulbol, G., Onlen, Y., Demir, C., Antibiotic resistance genes \& susceptibility patterns in staphylococci. Indian J Med Res., 135,
389-396 (2012).

26. LaPara, T., Burch, T., McNamara, P., Tan, D., Yan, M., Eichmiller, J., Tertiarytreated municipal wastewater is a significant point source of antibiotic resistance genes into Duluth-superior harbor. Environ. Sci. Technol. 45, 9543-9549 (2011).

27. Everage, T.J., Boopathy, R., Nathaniel, R., LaFleur, G., Doucet, J. A survey of antibioticresistant bacteria in a sewage treatment plant in Thibodaux, Louisiana, USA. Inter. Biodeter. \& Biodegr. 1- 9 (2014).

28. Huang, J.J., Hu, H.Y., Lu, S.Q., Li, Y., Tang, F., $\mathrm{Lu}, \mathrm{Y}$., Inactivation and reactivation of antibioticresistant bacteria by chlorination in secondary effluents of municipal wastewater treatment plant. Water Research, 45, 2775-2781 (2011).

29. Sullivan, B.A., Vance, C.C., Gentry, T.J., karthikeyan, R., Effects of chlorination and ultraviolet light on environmental tetracycline resistant bacteria and tet (W) in water. J. Environ. Chem. Eng.,5, 777-784 (2017).

30. Kouame, Y., Haas, C.N., Inactivation of $E$. coli by combined action of free chlorine and monochloramine. Water Res., 9, 1027-1032, (1991).

31. Mir, J., Morato, J., Ribas, F., Resistance to chlorine of freshwater bacteria strains. J. Appl. Microbiol. 82, 7-18 (1997).

(Received 29/8/2018; accepted 19/9/2018) 


\section{التأثير الكيميائي لعملية الكلورة علي البكتيريا المقاومة للمضادات الحيوية \\ سلوي سمير محمد'، سمر سمير محمد`، أحمد محمود شعبان'، يسرية حسن شتية'، محمد محمد كامل'

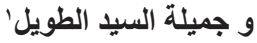

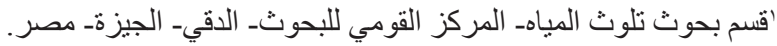

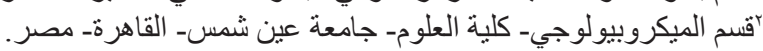

أجريت الدر اسة الحالية لتقييم فعالية الكلور كتطبيق بسيط ورخيص لإبطال نشاط البكتيريا المقاومة للمضادات الحيوية.

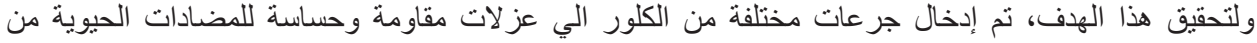

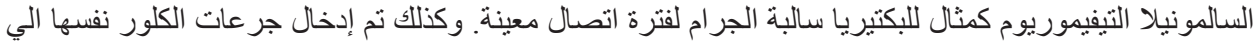

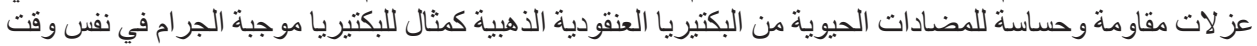

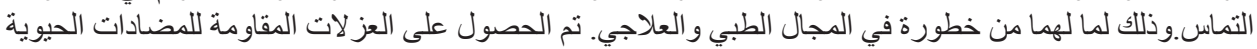

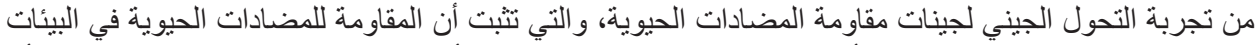

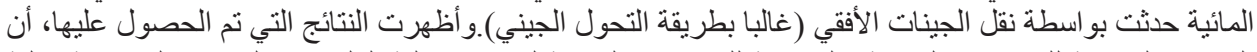

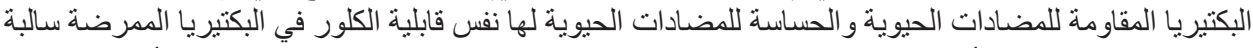

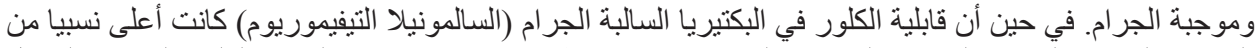

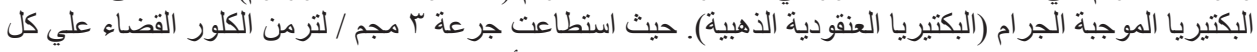

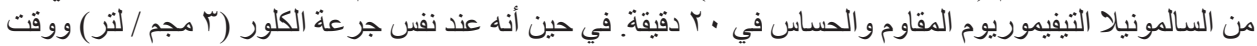

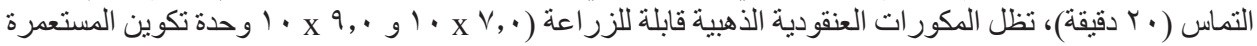

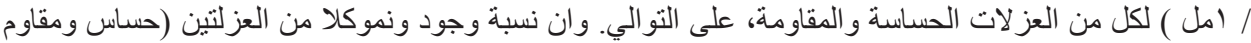
للمضادات الحيوية) يربطهما علاقة عكسية بنسبة الكلور المضية المضافة المية. 